\title{
A Bridge to Portugal: Language and Identity in Bridgeport, CT
}

\author{
FABIO SCETTI \\ Université Paul Valéry Montpellier 3 - DIPRALANG \\ McGill University - CRIM
}

\begin{abstract}
Here I present the results of BridgePORT, an ethnographic study I carried out in 2018 within the Portuguese community of Bridgeport, CT (USA). I describe language use and representation among Portuguese speakers within the community, and I investigate the integration of these speakers into the dominant American English speech community. Through my fieldwork, I observe mixing practices in day-to-day interaction, while I also consider the evolution of the Portuguese language in light of language contact and speakers' discourse as this relates to ideologies about the status of Portuguese within the community. My findings rely on questionnaires, participant observation of verbal interaction, and semi-structured interviews. My aim is to show how verbal practice shapes the process of identity construction and how ideas of linguistic "purity" mediate the maintenance of a link to Portugal and Portuguese identity.
\end{abstract}

Keywords: Portuguese, migration, diaspora, language contact, language ideologies

What In diasporic and migratory contexts, it is important to consider the linguistic landscape and analyze speakers' use of their heritage language. Central to this consideration is an examination of the integration process and the role of local institutions developed for this purpose. In the present article, I show how the Portuguese community in Bridgeport, CT (USA) has evolved since the 1920s and how its members have been able to build a "bridge" that connects Portugal to their new home: The Portuguese district of Bridgeport, located in an area known as the Hollow.

Employing an ethnographic approach, I present an overview of the present- 
day community, one that examines local institutions and cultural events within the group as well as the group's relation to other Portuguese communities in neighboring states. My goal here is to help to develop a better understanding of the concept of power in relation to language and verbal practice (Kachru), ethnolinguistic vitality (Bourhis, Giles, and Rosenthal; Harwood, Giles, and Bourhis), and the role of education in the process of identity construction (Calvet).

Beyond ethnographic description, I also analyze specific forms of linguistic and discursive data. This analysis focuses on verbal practice in the community today, with a particular focus on language mixing and variety-especially with respect to Brazilian and European Portuguese (Silva and Gunnewiek). These data are especially relevant in light of the arrival of Brazilian immigrants to Bridgeport and their integration within the Portuguese community. In terms of discursive analysis, I explore how speakers link their own verbal practice to identity construction. Central to this analysis is how speakers make use of community institutions to defend certain forms of verbal practice, especially for school-age children, and how actors promote certain discourses and language ideologies through the school (Errington 110; Kroskrity; Woolard).

\section{Historical Overview: The Portuguese Community in Bridgeport}

The Bridgeport Portuguese community is the largest of its kind in Connecticut. Most of the community has roots in Trás-os-Montes, and they first settled in Bridgeport in the 1920s, in an area then predominantly occupied by Azorean immigrants. After the Great Depression, a large number of Portuguese migrants returned to Portugal or moved to other destinations. Many of these resettled in Bridgeport after World War II (Penczer), and their numbers grew with the reformation of US immigration laws in $1965 .{ }^{1}$ This allowed entire families from Portugal to merge, and today there are approximately 19,000 Portuguese immigrants and/or their descendants in Bridgeport (U.S. Census Bureau).

Early in the twentieth century, the Portuguese community created its own

\footnotetext{
1 The Immigration and Nationality Act (1965), also called Hart-Celler Act, abolished the Emergency Quota Act (1921), which imposed a quota system based on national origins. The 1921 law created preference visa categories based on immigrants' skills and family relationships with citizens or US residents.
} 
"island" within the diverse social landscape of Bridgeport. By 1936, almost onethird of Bridgeport's population was foreign-born (Danenberg), and the city was enjoying a boom in manufacturing that allowed immigrants to find work quickly and promoted a fundamental openness to diversity in the city. Signs of this diversity are still visible. On the West Side, for example, there are neighborhoods still referred to as "Hungtown" (Hungarians) and "Hebrewhood" (Jews) close to Park Avenue. There are also clubs and associations such as the Swedish Singing Norden-Club on Seabright Avenue, which still flies a Swedish flag on its roof. On the East side, there is the Polish White Eagle Club and Saint Michael's Catholic Church next to the Polish Center for Language and Culture. Not far off, there is the Ukrainian Catholic Church of Washington Park. In terms of the descendants of immigrants, the North End of the city is still predominantly occupied by Italian and Irish Americans, and the Hollow is historically recognized as the Portuguese area of Bridgeport (Grimaldi). It is for this reason that the Portuguese community continues to defend its existence within the diverse puzzle now commonly referred to as "Park City."

\section{The Methodological Approach}

I conducted my ethnographic fieldwork in Bridgeport between January-March of $2018 .^{2}$ It consisted primarily of questionnaires, semi-structured interviews, and participant observation within the Portuguese community. As part of this fieldwork, I also collected and analyzed data related to community members' day-to-day language and literacy practices in Portuguese. In all of this, my aim was to gain a sense of how (and to what extent) Portuguese serves as a marker of community members' diasporic identity.

I first collected 30 questionnaires from Portuguese speakers within the community. From these questionnaires, I selected 16 speakers of different ages, genders, occupations, educational levels, and origins. I conducted these interviews mainly in private places or in institutional settings, such as the community school, the local church, and the Clube Português Vasco da Gama (= the Clube), for a total of approximately two hours and 15 minutes. I conducted

\footnotetext{
2 Financed by the Association Internationale d'Études Québécoises (AIEQ)—Tournée Internationale d'Expert.
} 
further interviews with community leaders: Padre José, a priest and director of the Elsa Cardoso community school, and staff members of the Clube. Observations of verbal practice took place weekly at the Clube and two evenings a week at the community school.

In terms of order and organization, I first transcribed the collected data and then examined them for features of spoken Portuguese. I was able to highlight elements of attrition and analyze different varieties of Portuguese, including nonstandard ones. I also underscored the ways in which speakers strategically mixed linguistic varieties and languages in their everyday verbal practice. This allowed me to identify discourses within the community that shape (and are shaped by) the status of different forms of spoken Portuguese. Chief among these are ideologies of linguistic purity and Portuguese history, both of which link language to normative ideas of group identity.

The present essay contains extracts from interviews collected as part of my fieldwork. I present each speaker with their name, age, and country of origin (PT or BR). Members of the first generation (1G), immigrants who first arrived in the United States, mostly speak Portuguese language in everyday interactions. Speakers of the 2nd generation (2G) are members of the community who either arrived in the US very young or were born in the US to Portuguese parents. For them, the Portuguese language is present within the familiar or the semi-public spheres, inside the community. 2G speakers were often educated in Portuguese at the local community school. Members of the third (3G) and fourth (4G) generations are descendants (grandchildren or great-grandchildren) of Portuguese immigrants. For them, the use of Portuguese is usually limited to familial settings. For the more recent Brazilian immigrants, the generational split is different. Having arrived in Bridgeport during the 1990s, they have only first$(1 \mathrm{G})$ and second-generation $(2 \mathrm{G})$ members.

My own position as an outsider also shaped this study in significant ways. I frequently participated in activities promoted and organized by the group, and this created new opportunities for interviews - snowball sampling was used in these contexts to speak to hard-to-reach members within the community. Community members raised questions regarding my legitimacy and identity at different moments; however, these same members were consistently generous with their time and happy to educate me regarding their shared history and cultural practice. 


\section{Little Portugal in the Hollow}

The Portuguese community of Bridgeport resides downtown, in a sort of cavity called the Hollow (map 1). Like other Portuguese communities in North America, it is an "ethnic enclave" that has managed to maintain its culture, language, and tradition over time, although migration from Portugal has diminished (Zucchi). The Hollow is located between North Avenue to the north, Washington Avenue to the south, Park Avenue to the west, and Main Street to the east. It is a residential area with mostly single-family homes, although there is also a small number of grocery stores, restaurants, bars, and patisseries. The Portuguese community overwhelmingly identifies as Roman Catholic, and it was deeply involved in the construction of the Our Lady of Fátima church. It also collectively sponsored the creation of the Escola Vasco da Gama, a community school where Portuguese is taught, and established the only Portuguese club in town, the Clube Português Vasco da Gama, also referred to as the Clube. Today the church, school, and club serve as the hub of the Portuguese community's life, even if they are physically somewhat distant from each another.

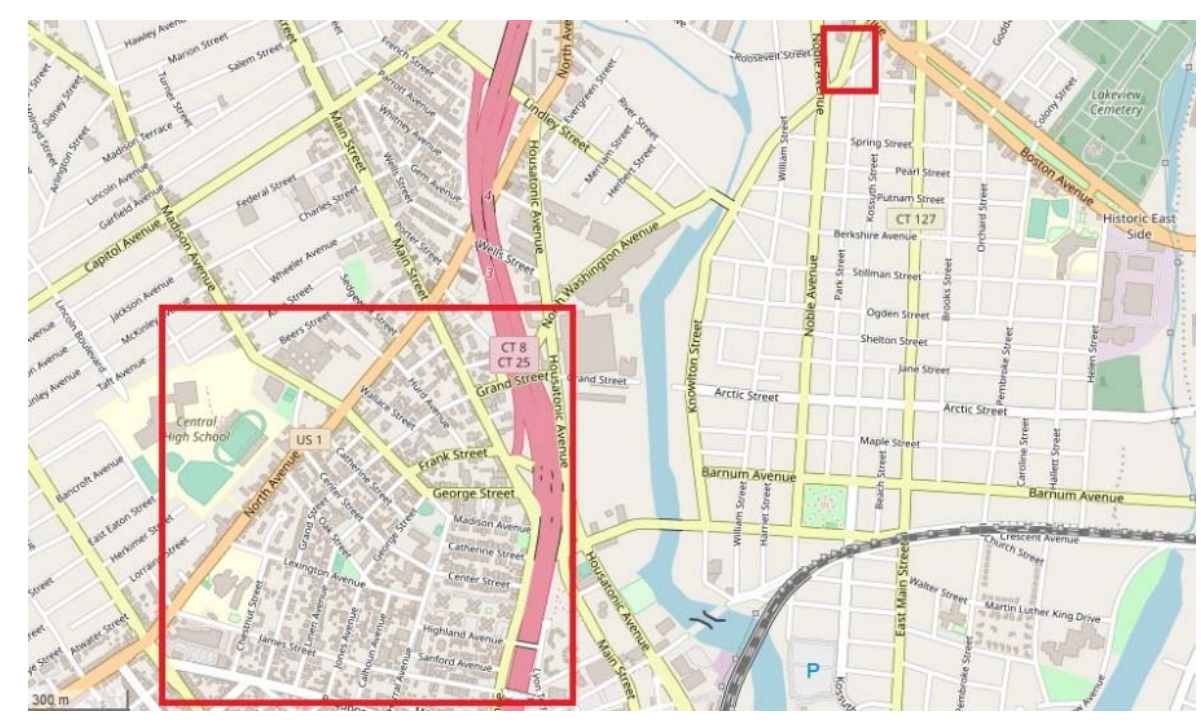

Map 1: Bridgeport with the Hollow (left) and site of Our Lady of Fátima Church (right) 


\section{Clube Português Vasco da Gama}

The Clube was founded in 1931, and since 1977, its headquarters has been located at 355 James Street. The book published on the occasion of the foundation's 75th anniversary speaks of its namesake as "leal e destemido," a fact that underscores the link forged between the early modern explorer and the migrations of the last two centuries. It was the first Portuguese club in the state, and today there are only four others (Hartford, Waterbury, Danbury, and Naugatuck) in Connecticut. ${ }^{3}$ The Clube is the biggest of these, with more than 700 members.

The Clube is strongly Portuguese. Cars and trucks parked outside are decorated with Portuguese flags and stickers or those of Portuguese football clubs, and at the entrance there is a flourishing collection of Portuguese symbols. The main entrance is controlled by a magnetic door access control kit. Only members can enter easily. Inside, the bar is situated in the middle, like an island. It is surrounded by tables, chairs, and a showcase with all the trophies of the local football club at the Luso-American Soccer Tournament of Champions of the East Coast and trophies from the American Pool Players Association. Pictures of Lisbon, Sintra, or villages located in Northern Portugal decorate the walls. Several televisions are switched on, and while one screen displays the names of all the association's members, others are set to RTP, Portugal's national network.

Portuguese is the main language spoken within the Clube, although English is present together with Spanish. During one of my visits, a bartender in the Clube, a native of Mexico, whispered to me, "Los obligo a hablar en español" 'I make them speak in Spanish.' She described the place from a distant point of view and remarked that during the week, her clients were mainly men. Clube members can show up at any time, and they often play cards, drink, and eat together. Many come in the morning and during their lunch break, when they can order from a menu of Portuguese cuisine. The oldest member of the community, 98 years old at the time of my fieldwork, visits the club every day. The bartender smiles: "Es como si fuera su trabajo" 'It's as if it were his job.' During weekends, members meet with friends and often bring their whole families. Women tend to

\footnotetext{
${ }^{3}$ In Danbury, there were two clubs, one for Portuguese from continental Portugal and the other founded by Azoreans. They have since merged into one club.
} 
visit the Clube during the weekend. In fact, during my Monday-Friday visits, I only met three women: a waitress from Cape Verde and two bartenders from Mexico. One of the latter, aged around 40, explained to me that: "Las cosas están cambiando; hay más mujeres que vienen, vienen con las amigas" 'Things are changing; more women are coming, and they come with their friends.' Gender roles have radically changed in Portuguese culture since the fall of the fascist regime in 1974. There were few opportunities for women before then, and it is possible that this situation is still reflected in the migrant context. José R. (1G 1950, PT), the president of the Clube, explained these changes from his perspective, mentioning that when he lived in Portugal it was rare for women to have a driver license. "Só as prostitutas tinham carta," he offered, adding that those women who legitimately needed a license could still be judged negatively.

\section{The Religious Center of Our Lady of Fátima}

In 1961, community members purchased land a few miles east of the Hollow, at the intersection of Huntington Road and Noble Avenue. Here they built a religious center named for the Virgin of Fátima. The center consists of a Roman Catholic church, Our Lady of Fátima, a catechetical center, and the priest's residence. The church is part of the Diocese of Bridgeport, and the priest at the time of my fieldwork was from Portugal. Before 1961, one could attend Portuguese mass only at Bridgeport's Saint Augustine cathedral.

Our Lady of Fátima still offers Portuguese mass; however, one perceives the importance and dominance of English in the church's (English) name. The interior of the church is very modern. There are stained-glass windows with English inscriptions for saints and stations of the cross. There are, however, symbols related to Portugal, such as the Portuguese flag and cross. The booklet of liturgical chants and sermons is bilingual. During our interview, Padre José admitted that the community is getting older and that since the 1970s, the church has offered catechism and mass for children (Sundays at 11am) in English only. At the time of my fieldwork, nearly 100 children were attending these classes, and they were all speaking English to each other. "Em português era perder tempo," Padre José confirmed.

The church oversees different cultural and religious events, which mix American and Portuguese festivities and are still very representative of 
community life. For instance, on the third Sunday of June, Father's Day in the United States, the community organizes a common picnic. On the 3rd Sunday of September, they organize a procession around the district with a band to celebrate the church's anniversary. Padre José explained that the community also used to celebrate Portugal Day (10 June), with a commemorative mass and religious/folkloric procession that ended with a common dinner offered at the Clube. This event no longer takes place, a fact that suggests a decline in terms of cultural and traditional activism.

"É uma comunidade que se sente abandonanda," Padre José told me, admitting that the community is shrinking and that fewer people attend mass at his church. People may now live far away or have a weaker connection to Catholic life. In the two manuscripts published by the church, for the 25th and the 50th anniversaries, however, I did notice a large number of advertisements for local Portuguese companies, a fact that suggests that local businesses at least continue to find value in institutions such as the church.

In terms of church's publication, I observed that older documents are only in Portuguese, sometimes with accents and tildes handwritten. In newer documents, including the anniversary manuscripts, texts tend to be bilingual. The institution's need to communicate to a larger public is understandable; however, this also means that English is quickly replacing Portuguese altogether, since younger community members are now unaccustomed to Portuguese.

\section{Escola Vasco da Gama Opens its Doors}

In light of the general shift toward English, Portuguese language instruction has become a priority for the community. According to Elsa Cardoso, the current director of the Escola Vasco da Gama in Bridgeport, Portuguese lessons have been offered to children born of Portuguese immigrants since the beginning. At first, she told me, a Portuguese teacher would offer "cursos de português durante os fins-de-semana numa garagem do bairro." In the late 1950s, this instruction moved to a new community school named for Vasco da Gama.

The community school never had its own building. It was initially set up in a section of the Clube, but it moved to the Our Lady of Fátima complex in 2015. Classes take place on Monday and Wednesday evenings from 6:00-7:30 pm. Children are welcomed for primary and secondary education in Portuguese, from 
6 to 13 years old. In the 1980 s, the school reached a total of 170 students; however, at the time of my fieldwork, I counted only 60 students. Children are mainly from Portuguese families, but many now have only one parent of Portuguese origin. Given the large number of recent immigrants from Brazil, the school is seeing an increasing number of children with Brazilian roots. Padre José spoke to me about the role of the school, pointing out that young couples in the community tend only to speak English, and as a result, the children have contact only with that language. "Não é a escola que lhe ensina o português," he added. "A escola é útil se em casa fala-se português, assim se pode aperfeiçoar."

In the past, the community also offered exchange programs with Portugal. The National Civil League, for example, used to provide scholarships for Portuguese students to come to the U.S. to study. The idea behind this exchange was to keep the community alive and maintain a direct contact between Bridgeport and Portugal. In the absence of such programs, the only viable solution to keep the school open is to welcome Brazilian immigrants into the community. "Com os brasileiros a entrar, os números estão a subir," Padre José confirmed. The community should open its doors to these new immigrants, he maintained, adding that if they do not, the school "pode durar só 20, 25 anos."

\section{The Purity of Portuguese, a Marker of the Community's Identity}

Upon identifying the main cultural institutions within the Portuguese community in Bridgeport, I turned to the role of Portuguese language in everyday verbal interaction. Portuguese remains a part of the community's linguistic repertoire, although there are significant differences in terms of fluency and accuracy that correspond to factors such as age, generation, education, and professional situation.

In the past, $1 \mathrm{G}$ speakers arrived in Bridgeport and seldom worked to maintain the active use of Portuguese outside of family settings. Men mostly worked in construction, and women were often hired to work in nearby factories. One can still observe construction workers at the Clube having lunch and speaking Portuguese with their co-workers, and it is reasonable to assume that Portuguese is still a working language throughout this sector. Community members still speak Portuguese at home, and all the interviewees confirmed that they speak Portuguese with family members; however, its presence and use vary from one 
home to another. For $1 \mathrm{G}$ immigrants, Portuguese is seldom the only language spoken, and 2G and 3G Luso-Americans tend to mix Portuguese with English. As a rule, older community members tend to speak mostly in Portuguese; however, this can change quickly when younger members are present. Fernando F. $(1 \mathrm{G}-1958, \mathrm{PT})$ told me that when a non-Portuguese speaker comes to his home, it requires effort to communicate with them in English: "Em minha casa, não se fala inglês, fazemos um esforço só para a namorada do meu filho que diz, 'English please!'” According to Fernando, younger members of the community tend to speak less Portuguese once they get married. José R. (1G - 1950, PT) added: "os jovens quando se casam com estrangeiras, fogem para o inglês," focusing on the influence of the (feminine) "foreign" partner. He then brought up another interesting point, namely the difference between generations. $\mathrm{He}$ observed that his son spoke to him in Portuguese, but his grandchildren spoke only English: "O meu filho sempre fala para mim também o português [...], os netos só falam inglés." Paulo ( $2 \mathrm{G}-1981$, PT) likewise answered the question, "Qual é a língua que se fala em casa?" by explaining the difference between his two "casas," that of his parents (where Portuguese is spoken) and the one he shares with his wife. Paulo's wife is also of Portuguese descent; nonetheless, they mostly speak English with one another: "Em casa dos meus pais é português, com a minha esposa é mais o inglês." This is not the case for Patrícia (2G-1977, PT) and her husband, who speak to one another primarily in Portuguese: "O esposo é português, foi natural!" Despite this, Patrícia admitted that she and her husband speak more English when they are with their daughter. Changes in the dynamics and equilibrium of verbal practice within the family are a decisive factor; however, interaction at school and with friends is similarly important. To this point, Dina ( $2 \mathrm{G}-1982$, PT), a young mother who always spoke Portuguese with her daughter, explained how the latter would "escape" (switch) from Portuguese to English, the language she brought back home from school: "Escapa sempre para o inglês, antes até os dois anos era só em português."

Different forms of linguistic mixing are common in quotidian interactions within the community, even if local institutions such as the Escola Vasco da Gama encourage speakers to adhere to an established standard. Many of the community members I interviewed mentioned that mixing Portuguese and English was undesirable and even a threat to the purity of the Portuguese language. 


\section{Mixing Practices “Are Not Very Good”}

It is relatively common for members of the community, especially younger members, to mix Portuguese and English in their everyday speech. I observed different mixing practices that stemmed largely from the context of language contact. These include interference (structural, lexical, and phonetic), borrowings, and more extensive code-switching. In my fieldwork, I observed that switches between Portuguese and English occurred often when speakers came across highly contextualized, untranslatable, and isolated substantives or discursive markers. Speakers also made use of conjunctions or prepositional phrases in English, even when interviews were conducted in Portuguese. Such use seems to be unconscious, as I detected neither pauses nor repair

The following examples illustrate how speakers "bring" English into their Portuguese verbal practice. The exchange below is taken from the interview with José R. (1G - 1950, PT), a native of Minho. He married a woman from Trás-osMontes, whom he had met during military service, and they migrated to Bridgeport together in 1975. At one point in our conversation, he spoke of his work history: "Trabalhei na fábrica 22 anos, depois na piscina, depois reforma, mais pa' ter a união." The term união is a literal translation of the English term "union," and it stands in here for the Portuguese term sindicato. José left Portugal as a young man, and he was not wholly aware when he left of Portuguese politics or labor policies. The term união seems to encode a concept wholly related to society in the United States. In my interviews with Fernando F. (1G - 1958, PT), a native of Chaves, I similarly observed contextualized and domain-specific switches to English. When speaking of topics related to technology and his professional activity, for example, he would introduce English terms into his Portuguese, such as, "Preencheram na computer um claim." In this example, it is also worth noting that Fernando uttered both English terms with only slightly marked vowel pronunciation.

The next three examples differ from the ones cited above in that they represent discursive markers common to colloquial Portuguese that popped up frequently during my observations. In the first example, Nick $(3 \mathrm{G}-1986, \mathrm{PT})$ is from Fall River, MA, and I met him at the Clube during one of his visits to Bridgeport. Paulo (2G - 1981, PT) and Elisabete $(2 \mathrm{G}-1980, \mathrm{PT})$ are from Bridgeport. Their families are originally from Trás-os-Montes, and I interviewed 
them at the community school.

(1) Nick: "Estás a ver, é como, like, ter o próprio espaço."

(2) Paulo: "Mas, I think, o - a cultura portuguesa é uma cultura muito bonita."

(3) Elisabete: "Só quando comecei a escola, you know, comecei mais a falar."

Switches to English often occur in this way in Portuguese conversation. Discursive markers such as "like," "I think," "you know," or "so," "well," and "ok," were common features of speech collected as part of my fieldwork.

In general, the use of English nouns (e.g., computer in lieu of computador) was more common in interactions or interviews with $1 \mathrm{G}$ speakers. These nouns were sometimes adapted in terms of use and pronunciation, and they were often shared by other members. I also detected different discursive markers that were more common among younger $2 \mathrm{G}$ and $3 \mathrm{G}$ speakers (e.g., "I think" and "you know"). In fact, $2 \mathrm{G}$ and $3 \mathrm{G}$ speakers seem to share English and Portuguese almost evenly in their linguistic repertoire and in their day-to-day interactions.

Members of the community tend to have differing opinions about mixing Portuguese and English. In fact, speakers are often unaware of this mixing, and they defend their Portuguese as "good," in terms accepted and promoted by local institutions. In addition, there is a general fear in the community of losing Portuguese and an awareness of the diffusion of English. Fernando M. (1G 1966, PT) put it succinctly: "A mixtura não faz muito bem."

\section{Discourses and Ideologies Promoting “Good” Portuguese}

At the Our Lady of Fátima church, English has eclipsed Portuguese, while at the Clube, Portuguese remains the main language. Nevertheless, Clube members are aging, and activism has begun to stagnate. The Escola Vasco da Gama promotes the use of Standard European Portuguese, even if pupils prefer to speak English during breaks. These three institutions show the loss of Portuguese verbal practice; however, there is a will among some to continue promoting its use.

Padre José underscored the importance of speaking Portuguese at home; 
however, some members of the community consider institutions such as the schools to be the best option for this purpose. Paulo ( $2 \mathrm{G}-1981$, PT), for example, underlined the "essential" position of the school: "Na escola portuguesa é onde aprendi a falar e a escrever, até o $6^{\circ}$ ano, também aprendi a história. A escola é essencial, you know, era uma obrigação." Besides the fact that the school is important in terms of acquiring literacy and learning about Portuguese history and culture, Paulo emphasized how school is "essential in learning how to speak." This reflects a common ideology in the community that the school is the best source for acquiring Standard European Portuguese.

In my observations, students at the Escola Vasco da Gama routinely addressed their peers in English, both in and out of class. It is possible that Portuguese was already too remote for them ( $3 \mathrm{G}$ and $4 \mathrm{G}$ descendants), or perhaps they lacked any real desire to master it. Eliane Rubinstein-Ávila has observed a similar situation in a different Portuguese-English dual immersion programs in New England. One complicating factor in the case of Bridgeport, however, is the increasing presence of speakers of Brazilian origin. Their impact on the Bridgeport Portuguese community leads to an explicit consideration of language standardization, ideology, and symbolic power.

At the Escola Vasco da Gama, most students of Brazilian origin speak Portuguese at home with their $1 \mathrm{G}$ parents, and they speak to their peers at school in both Portuguese and English. Julia (2G - 2005, BR), a teenager from Minas Gerais, affirmed: "Falo em casa, eu tenho dois relati na família que falam português [poRtu'gejs].” One immediately notices her fluency in Brazilian Portuguese, which far exceeds that of her Luso-American classmates. Norelisa ( $3 \mathrm{G}-2002$, PT-BR) is another good example, as she has steady contact at home with both European and Brazilian Portuguese. She was raised in Bridgeport by her Brazilian mother and a stepfather of Portuguese origin. "Nós [nois] sempre falamos português lá em casa, mas eu às vezes falo inglês com a minha mãe porque ela entende [int3ndzi]," she told me, adding that she is able to switch easily from "her" to "his" variety of Portuguese.

These two examples help to illustrate how recent migration from Brazil is reshaping the linguistic repertoire and verbal practice of the Portuguese community in Bridgeport. European Portuguese is still the de facto standard at the Escola Vasco da Gama, however, since the teachers all come from Portuguese families within the community. In focusing on European Portuguese, these 
instructors seem not to consider the social and political aspects of linguistic variety and language use within the Lusophone world, mainly in reference to this new wave of Brazilian migration. According to what these instructors told me, they are focused on the promotion of a "pure" form of Portuguese language and historicity. This has also been observed in public school contexts across the United States and Canada, despite the number of multilingual students involved (Heller and Martin-Jones). Another level of complexity is that community members also consider the school to be where young people learn to be good citizens. In the case of Escola Vasco da Gama, this includes learning to be what community leaders consider good members of the community and, by extension, good speakers of Portuguese.

Within the Portuguese community of Bridgeport, I observed different forms of Portuguese spoken at school, at home, and around the Hollow. In the first place, speakers often mix Portuguese with English. This is notable, since even in light of the high prestige afforded Standard American English both within and beyond the community, mixing Portuguese with it is uniformly discouraged. Local institutions also defend the European norm, as community members consider this to be the most prestigious form of Portuguese. Brazilian Portuguese is present mostly at the familial level, and there are currently no efforts to promote or defend it.

The relation between language and identity is fundamental insofar as individuals engage in verbal practice to perform and/or achieve a given identity. In the examples below, José P. (2G - 1970, PT) switched to English while talking about his status as a Luso-American petitioning for Portuguese citizenship: "Sou aqui um American citizen, mas também estou a tentar buscar duas citizenship agora." Elisabete ( $2 \mathrm{G}-1980, \mathrm{PT})$ likewise affirmed that Portuguese is important for her, stressing the fact that her passport is a reflection of her identity. She wanted to show her ability to exercise "flexible citizenship" (Ong), and when I asked her, "Como te sentes?" she answered: "Portuguesa, yeah! I mean, o meu passaporte é ainda português, eu não vou trocar." She then laughed, adding: "Não quero ser citizen!" switching again to English.

Identity is complex and dynamic, and it is linked to the language-learning process (Norton \& Toohey, 2011). The examples above show how important the relation between language and identity - and even citizenship - can be. Even if José and Elisabete are $2 \mathrm{G}$ Luso-Americans, they live multiple forms of 
nationality and citizenship (Jordan and Düvell 77). It is to be assumed that using English on these occasions relates to one's American identity, since having American citizenship is typically linked to the fact of speaking English. In the same way, the "good" use of Portuguese still correlates with being a "good" Portuguese person, or rather a "good" member of the community (Scetti).

\section{Conclusion}

The neighborhood of Little Portugal in the Hollow is well known within the city of Bridgeport. Also well known, largely due to their many activities, are the Clube, the Escola Vasco da Gama, and the Our Lady of Fátima church. Portuguese is still used daily in this public area, and this district continues to represent the Portuguese "soul" of Bridgeport.

Today the city of Bridgeport is experiencing real change. Known as the financial center of the entire state of Connecticut, the city is suffering the consequences of economic and financial crisis. The area downtown is impoverished, and many buildings and businesses have been abandoned. It resembles a ghost town in many ways, and yet other groups are gradually settling there. For this reason, talk of fear, violence, and prejudice circulates within the Portuguese community with respect to the new arrivals to "their" neighborhood. The Hollow is living through a veritable economic depression, and Little Portugal seems to be disappearing. Brazilian, Mexican, and Puerto Rican businesses, among others, are replacing Portuguese stores and facilities, and Spanish is increasingly becoming a language of daily interaction within the area.

Walking around the Hollow, one hears a fair amount of Brazilian Portuguese, which José R. (1G - 1950, PT) refers to as: "um outro português.” Moreover, a new rivalry has emerged between the two groups. The Brazilian community that started settling in Bridgeport in the 1990s used to rent out the Clube for their celebrations, such as Carnival. Today they have their own clubs, and they have also opened many restaurants. From José's perspective, the influx of Brazilian residents and businesses represents "uma verdadeira invasão."

Residents of the Hollow make extensive use of Portuguese, even if a new "flavor" is noticeable. This does not mean that Portuguese has made many inroads outside of the Hollow. Members of the community are well aware of the global reach of the Portuguese language. Armando (1G - 1966, PT), for example, 
even significantly inflates the number of global Portuguese speakers: "Há 400 milhões de falantes de português no mundo." In the US, however, bi/multilingualism is often framed in a negative manner (Lippi-Green). Bilingual Spanish-English speakers tend to dodge this stigma, but this is due mainly to the overwhelming presence of Spanish in the US (Portes and Rumbaut). Education is a fundamental aspect of identity formation, and schools still tend to promote an explicitly assimilationist model (Alba and Nee).

When it comes to Portuguese, being a speaker of the European or Brazilian variety is not important to all community members. As Norelisa (3G - 2002, PTBR) points out, it depends largely on context: "Então, quando vou para Portugal eles falam: 'Oh! você é brasileira,' mas quando vou pa' o Brasil eles falam: 'Oh! você é portuguesa' [...] eles riem, 'tu es [3]] portuga né?'” Speaking with me, Norelisa's Portuguese changed from one regional variety to another almost effortlessly. The only constant was that she stressed her [J] endings (with the voiceless palato-alveolar fricative), as is common in European Portuguese. What matters, at least for her, is that one continues to speak Portuguese, without a concern for varietal "purity," in a context where English is dominant. Her message to me was clear. If one wishes to maintain a language, it is necessary to speak it: "Se tem de falar uma língua."

Speaking Portuguese is an important marker of identity in the Hollow. As Lynn Owen Penczer has pointed out, the ability to use the language correctly has long been one of the most valued markers of education within the group. ${ }^{4}$ Even so, I observed many examples of linguistic mixing during my fieldwork. This was variable by speaker and context, and these examples run against the community's emphasis on linguistic "purity," an emphasis that likely stems from an imagined sense of "common diasporic identity" (Rosa and Trivedi). This common identity leads one to question the validity of a nationalist linguistic paradigm, or the idea that a given language is somehow linked to a given nation (or community, in this case). Out of such questioning can emerge new ideas about language and how it can be integrated into a new system of valuation, one that works in tandem with newer conceptions of self (Park 557).

Speaking "good" Portuguese in the Hollow remains a kind of "bridge" between the Portuguese community of Bridgeport and "their" Portugal. Given

\footnotetext{
${ }^{4}$ Penczer carried out her fieldwork between 1977 and 1985.
} 
the decline of the community, however, new ideologies surrounding Portuguese may yet serve as an important element to build or maintain other connections with the new Brazilian reality within the district. In this sense, new controversies and disagreements may arise as to which variety properly represents a common heritage. The image of a bridge, as well as the image of the open doors at the community school, may be understood as the creation of the link between Portuguese speakers and both communities. A new vision of linguistic variation and Lusophony that does not privilege the imperial past may yet emerge as a positive strategy in promoting the use and teaching of Portuguese within the United States, beyond its uneven transmission as a heritage language.

\section{Works Cited}

Alba, Richard, and Victor Nee. "Rethinking Assimilation Theory for a New Era of Immigration." The International Migration Review, vol. 31, no. 4, 1997, pp. 826-74.

Bourhis, Richard Yvon, Howard Giles, and Doreen Rosenthal. "Notes on the Construction of a "Subjective Vitality Questionnaire" for Ethnolinguistic Groups. Journal of Multilingual and Multicultural Development, vol. 2, 1981, pp. 145-55.

Calvet, Louis-Jean. Language Wars and Linguistic Politics. Oxford UP, 1998.

Danenberg, Elsie Nicholas. The Story of Bridgeport, 1836-1936. Bridgeport Centennial, 1936.

Errington, Joseph. "Ideology." Key Terms in Language and Culture, edited by Alessandro Duranti, Blackwell, 2001, pp. 110-12.

Grimaldi, Lennie. Only in Bridgeport: An Illustrated History of the Park City. Windsor, 1993.

Harwood, Jake T., Howard Giles, and Richard Yvon Bourhis. "The Genesis of Vitality Theory: Historical Patterns and Discoursal Dimensions." International Journal of the Sociology of Language, vol. 108, 1994, pp. 167206.

Heller, Monica, and Marilyn Martin-Jones. Voices of Authority: Education and Linguistic Difference. Ablex, 2001.

Jordan, Bill, and Franck F. Düvell. Migration: The Boundaries of Equality and Justice. Polity, 2003. 
Kachru, Braj B. The Other Tongue: English Across Cultures. U of Illinois P, 1992.

Kroskrity, Paul V. "Language ideologies." A Companion to Linguistic Anthropology, edited by Alessandro Duranti, Blackwell, 2004, pp. 496-517.

Lippi-Green, Rosina. English with an Accent: Language, Ideology and Discrimination in the United States. $2^{\text {nd }}$ edition, Routledge, 2012.

Norton, Bonny, and Kelleen Toohey. "Identity, Language Learning, and Social Change." Language Teaching, vol. 44, no. 4, 2011, pp. 412-46.

Ong, Aiwha H. Flexible Citizenship: The Cultural Logics of Transnationality. Duke UP, 1999.

Park, Joseph S. "Metadiscursive Regimes of Diversity in a Multinational Corporation." Language in Society, vol. 42, 2013, pp. 1-21.

Penczer, Lynn Owen. The Family Comes First: Portuguese/Americans in Bridgeport, Connecticut. Oneonta, 2018.

Portes, Alejandro, and Rubén G. Rumbaut. Immigrant America: A Portrait, Updated, and Expanded, U of California P, 2014.

Rosa, Jonathan, and Sunny Trivedi. "Diaspora and Language." The Routledge Handbook on Migration and Language, edited by Suresh Canagarajah, Routledge, 2017, pp. 330-46.

Rubinstein-Ávila, Eliane. "Problematizing the 'Dual' in a Dual-Immersion Program: A Portrait." Linguistics and Education, vol. 13, no. 1, 2002, pp. 65-87.

Scetti, Fabio. La communauté portugaise de Montréal: langue et identité. U Laval P, 2019.

Silva, Jaime F. da, and Lisanne Klein Gunnewiek. "Portuguese and Brazilian Efforts to Spread Portuguese." International Journal of Sociology of Language, vol. 95, 1992, pp. 71-92.

U.S. Census Bureau. "American Community Survey 5-Year Data (2009-2018)." 19 Dec. 2019, www.census.gov/data/developers/data-sets/acs-5year.html.

Woolard, Kathryn. "Introduction: Language Ideology as a Field of Inquiry." Language Ideologies: Practice and Theory, edited by Bambi B. Schieffelin, Kathryn Woolard, and Paul V. Kroskrity, Oxford UP, 1998, pp. 3-47.

Zucchi, John. A History of Ethnic Enclaves in Canada. Canadian Historical Association, 2007. 